\title{
Decision-Making Styles of Young Chinese, Motswana and Caucasian Consumers in South Africa: An Exploratory Study
}

\author{
Laetitia Radder, Yuejin Li and JJ Pietersen
}

\begin{abstract}
OPSOMMING
Suid-Afrikaanse bemarkers word toenemend gekonfronteer deur die invloed van globalisering op die markomgewing. Nie net moet hulle rekening hou met die aankoopbesluitnemingspatrone van Suid-Afrikaanse verbruikers en verbruikers in buitelandse markte nie, maar toenemend ook met dié van buitelandse verbruikers wat hulle tydelik in Suid-Afrika vestig. Studente verteenwoordig ' $n$ belangrike groep sodanige verbruikers.
\end{abstract}

Verbruikersbesluitneming tydens aankope is ' $n$ komplekse proses. In die soeke na 'n universeel bruikbare matriks om verbruikersbesluitnemingsgedrag onder verskillende kulture te tipeer, het Sproles en Kendall (1986) 'n verbruikersbesluitnemingsindeks (VBI) ontwikkel. Agt besluitnemingstyle is in hierdie matriks getoets, naamlik dié van perfeksionisme/kwaliteitbewustheid; handelsmerkbewustheid; nuutheid/modebewustheid; ontspanning/ hedonisme; prys/waardebewustheid; impulsief/agtelosigheid; keuse-verwardheid en gewoonte/handelsmerkgetrouheid. Die instrument is in verskeie lande getoets, maar het gemengde resultate behaal.

Hierdie artikel rapporteer die toepaslikheid van die VBI in Suid-Afrika. In teenstelling met vorige studies, fokus die navorsing op verskillende kulture (een plaaslik en twee buitelands) binne dieselfde Suid-Afrikaanse markomgewing. 'n Geriefssteekproef van eenhonderd studente elk vanuit China, Botswana en Suid-Afrika is gekies. Slegs Blanke Suid-Afrikaners is ingesluit ten einde die invloed van verskillende inheemse SuidAfrikaanse kulture uit te skakel. Klerasie was die fokusproduk vir die navorsing. Nie net speel groepsdruk ' $n$ groot rol in studente se keuse van wat hulle dra nie, maar verteenwoordig ook dikwels hul aspirasies, fantasieë, affiliasie en selfs hul identiteit.

Tydens die toetsing van die Sproles en Kendall-matriks in die Suid-Afrikaanse situasie, kon slegs ses van die agt verbruikersbesluitnemingstyle deur die data van die Blanke steekgroep bevestig word, vier in die geval van die Chinese steekproef, en twee in die geval van die Motswana groep. Hierdie twyfelagtige toepaslikheid van die matriks in die Suid-Afrikaanse situasie is deur verdere statistiese toetse bevestig. Die Suid-Afrikaanse datastel is dus aan nuwe eksploratiewe toetsing onderwerp in ' $n$ poging om 'n meer aanvaarbare passing van die model te ondersoek. Hierdie keer is sewe besluitnemingstyle geïdentifiseer in die geval van die Blankes, en vyf vir elk van die Chinese en Motswana groepe. Drie gemeenskaplike besluitnemingstyle het onder al drie die bevolkingsgroepe voorgekom, naamlik dié van perfeksionisme, gewoonte, en ontspanning/ genotsoekend. Die individuele items wat die style beskryf, het egter verskil.

Uit die resultate blyk dit dus dat die oorspronklike VBI slegs na verskeie aanpassings binne ' $n$ Suid-Afrikaanse markomgewing gebruik kan word. Verdere ontwikkeling en toetsing van die model is dus nodig. Nuwe dimensies en selfs verdere besluitnemingstyle moet ondersoek word.

Die resultate het egter ook ' $n$ aantal tipiese eienskappe in die besluitnemingstyle van die drie bevolkingsgroepe aangetoon. Hoewel studente uit al drie kultuurgroepe neig om perfeksionisties te wees in hul aankope van klerasie, neig Chinese studente ook om meer gewoonte-gedrewe te wees. Motswana studente is weer meer bewus van beeld en kwaliteit, terwyl Blanke studente meer prysbewus is.

\section{- Prof L Radder}

Department of Marketing

Nelson Mandela Metropolitan University

- Ms Yuejin Li

Department of Marketing

Nelson Mandela Metropolitan University

\section{- Dr JJ Pietersen}

Department of Statistics

Nelson Mandela Metropolitan University

\section{Acknowledgement}

The financial assistance of the Nelson Mandela Metropolitan University towards this research is acknowledged. Opinions expressed and conclusions arrived at are those of the authors and are not necessarily to be attributed to the institution. 


\section{INTRODUCTION}

Globalisation of the marketplace is playing an increasingly important role in South Africa. Nowadays, South African marketers not only have to be informed about the decision-making processes of consumers in the rest of the world, but also have to understand the decision-making processes of consumers from a variety of countries who come to live in South Africa for varying periods of time.

International students represent one such group of consumers. It is estimated that 47000 foreign students are currently enrolled at South African tertiary institutions, each spending about R57 000 per annum. In 2006, 10,5\% of the residential students enrolled at the Nelson Mandela Metropolitan University in Port Elizabeth came from 60 foreign countries (Nelson Mandela Metropolitan University, 2006:25). The largest groups of foreign students were from Botswana and China, while the remainder came from countries such as Germany, the United States of America and Lesotho. The influx of foreign residential students results in a growing number of consumers making purchasing decisions connected to their daily lives within an unfamiliar marketing environment.

Marketers intending to enter or expand into international markets or serve different foreign cultures in a domestic market are more likely to succeed if they have a good understanding of the decision-making processes of the different cultural groups. Such knowledge can assist the marketer in more closely matching his marketing tactics, promotional efforts and positioning to the characteristics of the market.

Consumer decision-making is a complex process that significantly influences shopping behaviour. Four distinct views of consumer decision-making have been identified (Schiffman \& Kanuk, 2004:550-553) namely: an economic view, where the consumer is characterised as making rational decisions; a passive view, which perceives consumers as impulsive and irrational purchasers; a cognitive view, which accepts that consumers cannot make perfect decisions, but nonetheless actively seek information and attempt to make satisfactory decisions; and an emotional or impulsive view that recognizes that consumers often make careless decisions they later regret.

These four views of consumer decision-making can be explained in terms of the consumer decision-making styles index (CSI) developed by Sproles and Kendall (1986). The CSI describes eight types of shoppers: perfectionist/high quality-conscious shoppers; brandconscious shoppers; novelty/fashion-conscious shoppers; recreational/hedonistic shoppers; price-conscious/value-conscious shoppers; impulsive/careless shoppers; confused by over-choice shoppers; and habitual/brand-loyal shoppers. Each decision-making style represents a mental orientation characterising the consumer's approach to making choices.

The CSI provides a potentially useful instrument to assist marketers in examining consumer decisionmaking styles (Walsh et al, 2001). The CSI has been tested using various nationalities - Americans, Koreans, Chinese, Indians and Germans (Fan \& Xiao, 1998; Hafstrom et al, 1992; Lyonski et al, 1996; Walsh et al, 2001) - in an attempt to get a better understanding of consumer decision-making processes within different cultures. However, no research reporting either on the reliability of the CSI in South Africa, or the generalisability of the instrument across foreign and local cultures within a South African marketing environment could be traced via database searches. The purpose of this research was to test the CSI's reliability in South Africa and to identify the decisionmaking styles of Chinese, Motswana and Caucasian students enrolled at the Nelson Mandela Metropolitan University.

TABLE 1: DEMOGRAPHICS OF THE SAMPLE

\begin{tabular}{|l|c|c|c|}
\hline & Chinese & Motswana & Caucasian \\
\cline { 2 - 4 } & $\%$ & $\%$ & $\%$ \\
\hline Gender & & & 49 \\
\hline Male & 49 & 48 & 51 \\
\hline Female & 51 & 52 & 19 \\
\hline Age & & 5 & 74 \\
\hline$<20$ years & 10 & 76 & 6 \\
\hline $20-25$ years & 65 & 18 & 1 \\
\hline $26-30$ years & 20 & 1 & - \\
\hline$>30$ years & 5 & & - \\
\hline Period of stay in South Africa & & 12 & 100 \\
\hline $0-12$ months & 20 & 87 & \\
\hline $13-60$ months & 75 & 1 & 61 \\
\hline$>60$ months & 5 & & 31 \\
\hline Average monthly expenditure on clothing & & 6 & 6 \\
\hline$<$ R200 & 42 & 47 & 2 \\
\hline R200 - R500 & 44 & 40 & \\
\hline R501 - R1 000 & 11 & 7 & \\
\hline$>$ R1 000 & 3 & & \\
\hline
\end{tabular}




\begin{tabular}{|c|c|c|c|c|}
\hline & $\begin{array}{l}\text { USA } \\
\text { Sample }\end{array}$ & $\begin{array}{l}\text { Chinese } \\
\text { Sample }\end{array}$ & $\begin{array}{l}\text { Motswana } \\
\text { Sample }\end{array}$ & $\begin{array}{l}\text { Caucasian } \\
\text { Sample }\end{array}$ \\
\hline & $\begin{array}{l}\text { Item } \\
\text { loading }\end{array}$ & $\begin{array}{c}\text { Item } \\
\text { loading }\end{array}$ & $\begin{array}{c}\text { Item } \\
\text { oading }\end{array}$ & $\begin{array}{c}\text { Item } \\
\text { loading }\end{array}$ \\
\hline $\begin{array}{l}\text { Factor } 1 \\
\text { Perfectionist/high quality-conscious shopper }\end{array}$ & $\propto=0,74$ & $\propto=0,51$ & $\propto=0,78$ & $\propto=0,74$ \\
\hline Getting very good quality is very important to me & 0,68 & 0,42 & 0,58 & 0,64 \\
\hline $\begin{array}{l}\text { When it comes to purchasing clothing, I try to get the } \\
\text { very best or the perfect choice }\end{array}$ & 0,66 & 0,67 & 0,68 & 0,63 \\
\hline In general, I usually try to buy the best overall quality & 0,62 & 0,63 & 0,68 & 0,71 \\
\hline $\begin{array}{l}\text { I make special effort to choose the very best quality } \\
\text { clothes }\end{array}$ & 0,61 & 0,57 & 0,76 & 0,69 \\
\hline $\begin{array}{l}\text { I really do not give my clothing purchases much thought } \\
\text { or care }\end{array}$ & $-0,54$ & 0,07 & $-0,49$ & $-0,46$ \\
\hline $\begin{array}{l}\text { My standards and expectations for the clothing I buy } \\
\text { are very high }\end{array}$ & 0,54 & 0,42 & 0,35 & 0,65 \\
\hline $\begin{array}{l}\text { I shop quickly, buying the first product or brand I find } \\
\text { that seems good enough }\end{array}$ & $-0,41$ & $-0,13$ & $-0,52$ & $-0,13$ \\
\hline $\begin{array}{l}\text { A product does not have to be perfect, or the best, to } \\
\text { satisfy me }\end{array}$ & $-0,41$ & 0,34 & $-0,54$ & $-0,43$ \\
\hline$\%$ of item loadings 0,4 and above & 100,0 & 62,5 & 87,5 & 87,5 \\
\hline $\begin{array}{l}\text { Factor } 2 \\
\text { Brand-consciousl'price equals quality' shopper }\end{array}$ & $\propto=0,75$ & $\propto=0,63$ & $\propto=0,69$ & $\propto=0,76$ \\
\hline I prefer buying well-known national brands & 0,63 & 0,60 & 0,57 & 0,73 \\
\hline The most expensive brands are usually my choice & 0,61 & 0,52 & 0,74 & 0,72 \\
\hline The higher the price of a product, the better its quality & 0,59 & 0,74 & 0,50 & 0,27 \\
\hline $\begin{array}{l}\text { Nice department and speciality stores offer me the best } \\
\text { products }\end{array}$ & 0,57 & 0,39 & 0,50 & 0,37 \\
\hline I prefer buying the best-selling brands & 0,54 & 0,60 & 0,47 & 0,76 \\
\hline $\begin{array}{l}\text { The most advertised brands are usually very good } \\
\text { choices }\end{array}$ & 0,48 & 0,09 & 0,68 & 0,80 \\
\hline$\%$ of item loadings 0,4 and above & 100,0 & 57,1 & 85,7 & 57,1 \\
\hline $\begin{array}{l}\text { Factor } 3 \\
\text { Noveltylfashion-conscious shopper }\end{array}$ & $\propto=0,74$ & $\propto=0,63$ & $\propto=0,56$ & $\propto=0,64$ \\
\hline I usually have one or more outfits of the very latest style & 0,75 & 0,48 & 0,35 & 0,43 \\
\hline $\begin{array}{l}\text { I keep my wardrobe up-to-date with the changing } \\
\text { fashions }\end{array}$ & 0,70 & 0,28 & 0,55 & 0,57 \\
\hline Fashionable, attractive styling is very important to me & 0,64 & 0,53 & 0,45 & 0,35 \\
\hline To get variety, I shop at different stores & 0,50 & 0,16 & 0,47 & 0,23 \\
\hline It's fun to buy something new and exciting & 0,46 & $-0,32$ & 0,19 & $-0,15$ \\
\hline$\%$ of item loadings 0,4 and above & 100,0 & 40,0 & 60,0 & 40,0 \\
\hline
\end{tabular}




\begin{tabular}{|c|c|c|c|c|}
\hline & $\begin{array}{c}\text { USA } \\
\text { Sample }\end{array}$ & $\begin{array}{l}\text { Chinese } \\
\text { Sample }\end{array}$ & $\begin{array}{l}\text { Motswana } \\
\text { Sample }\end{array}$ & $\begin{array}{l}\text { Caucasian } \\
\text { Sample }\end{array}$ \\
\hline & $\begin{array}{c}\text { Item } \\
\text { loading }\end{array}$ & $\begin{array}{c}\text { Item } \\
\text { loading }\end{array}$ & $\begin{array}{c}\text { Item } \\
\text { loading }\end{array}$ & $\begin{array}{c}\text { Item } \\
\text { loading }\end{array}$ \\
\hline $\begin{array}{l}\text { Factor } 4 \\
\text { Recreational/hedonistic shopper }\end{array}$ & $\propto=0,76$ & $\propto=0,77$ & $\propto=0,59$ & $\propto=0,77$ \\
\hline Shopping is not a pleasant activity to me & $-0,70$ & 0,64 & 0,64 & 0,80 \\
\hline $\begin{array}{l}\text { Going shopping is one of the enjoyable activities of my } \\
\text { life }\end{array}$ & 0,70 & $-0,56$ & $-0,69$ & $-0,49$ \\
\hline Shopping at different stores wastes my time & $-0,69$ & 0,80 & 0,59 & 0,51 \\
\hline I enjoy shopping just for the fun of it & 0,66 & $-0,57$ & $-0,20$ & $-0,80$ \\
\hline I make my shopping trips fast & $-0,64$ & 0,77 & 0,38 & 0,75 \\
\hline$\%$ of item loadings 0,4 and above & 100,0 & 100,0 & 60,0 & 100,0 \\
\hline $\begin{array}{l}\text { Factor } 5 \\
\text { Price-conscious/'value-for-money' shopper }\end{array}$ & $\propto=0,48$ & $\propto=-0,25$ & $\propto=0,05$ & $\propto=0,08$ \\
\hline I buy as much of my clothing as possible at sale prices & 0,66 & 0,19 & 0,44 & 0,75 \\
\hline I usually choose lower priced products & 0,56 & 0,73 & 0,53 & 0,34 \\
\hline I look carefully to find the best value-for-money & 0,54 & $-0,38$ & $-0,27$ & 0,58 \\
\hline$\%$ of item loadings 0,4 and above & 100,0 & 33,3 & 66,6 & 66,6 \\
\hline $\begin{array}{l}\text { Factor } 6 \\
\text { Impulsive/careless shopper }\end{array}$ & $\propto=0,48$ & $\propto=0,49$ & $\propto=0,43$ & $\propto=0,55$ \\
\hline I should plan my shopping more carefully than I do & 0,55 & 0,43 & 0,55 & 0,40 \\
\hline I am impulsive when purchasing clothing & 0,53 & 0,46 & $-0,03$ & 0,66 \\
\hline $\begin{array}{l}\text { I often make careless purchases I later wish I had not } \\
\text { made }\end{array}$ & 0,52 & 0,43 & 0,67 & 0,60 \\
\hline I take time to shop carefully for the buys & $-0,51$ & $-0,54$ & $-0,42$ & $-0,01$ \\
\hline I carefully watch how much I spend on clothing & $-0,43$ & $-0,63$ & 0,20 & $-0,41$ \\
\hline$\%$ of item loadings 0,4 and above & 100,0 & 100,0 & 60,0 & 80,0 \\
\hline $\begin{array}{l}\text { Factor } 7 \\
\text { Confused by over-choice shopper }\end{array}$ & $\propto=0,55$ & $\propto=0,71$ & $\propto=0,47$ & $\propto=0,77$ \\
\hline $\begin{array}{l}\text { There are so many brands to choose from that I often } \\
\text { feel confused }\end{array}$ & 0,68 & 0,61 & 0,53 & 0,77 \\
\hline Sometimes it is hard to choose which stores to shop at & 0,61 & 0,52 & 0,71 & 0,59 \\
\hline $\begin{array}{l}\text { The more I learn about clothing products, the harder it } \\
\text { seems to choose the best }\end{array}$ & 0,53 & 0,40 & 0,27 & 0,61 \\
\hline $\begin{array}{l}\text { All the information I get on different products confuses } \\
\text { me }\end{array}$ & 0,44 & 0,73 & 0,53 & 0,69 \\
\hline$\%$ of item loadings 0,4 and above & 100,0 & 100,0 & 75,0 & 100,0 \\
\hline
\end{tabular}


TABLE 2: $\quad$ THE SPROLES AND KENDALL (1986) MODEL AS APPLIED TO THE SOUTH AFRICAN SAMPLES (continued ...l)

\begin{tabular}{|l|c|c|c|c|}
\hline & $\begin{array}{c}\text { USA } \\
\text { Sample }\end{array}$ & $\begin{array}{c}\text { Chinese } \\
\text { Sample }\end{array}$ & $\begin{array}{c}\text { Motswana } \\
\text { Sample }\end{array}$ & $\begin{array}{c}\text { Caucasian } \\
\text { Sample }\end{array}$ \\
\cline { 2 - 5 } & $\begin{array}{c}\text { Item } \\
\text { loading }\end{array}$ & $\begin{array}{c}\text { Item } \\
\text { loading }\end{array}$ & $\begin{array}{c}\text { Item } \\
\text { loading }\end{array}$ & $\begin{array}{c}\text { Item } \\
\text { loading }\end{array}$ \\
\hline $\begin{array}{l}\text { Factor 8 } \\
\text { Habitual/brand-loyal shopper }\end{array}$ & $\propto=\mathbf{0 , 5 3}$ & $\propto=\mathbf{0 , 4 8}$ & $\propto=\mathbf{0 , 3 2}$ & $\propto=\mathbf{0 , 6 5}$ \\
\hline I have favourite brands I buy over and over & 0,70 & 0,48 & 0,13 & 0,28 \\
\hline Once I find a brand I like, I stick with it & 0,60 & 0,65 & 0,48 & 0,69 \\
\hline I go to the same stores each time I shop for clothing & 0,58 & 0,78 & 0,60 & 0,68 \\
\hline I regularly change clothing brands & $-0,48$ & 0,25 & 0,52 & $-0,73$ \\
\hline \% of item loadings 0,4 and above & 100,0 & 75,0 & 75,0 & 75,0 \\
\hline
\end{tabular}

$\propto=$ Cronbach's coefficient alpha

\section{CONSUMER DECISION-MAKING STYLES}

Sproles and Kendall (1986) argue that identifying the basic characteristics of decision-making styles can help profile an individual's decision-making characteristics and counsel families on financial management. Based on the major characteristics of consumer decision-making identified in literature, the authors formulated a measurement of consumer decision-making styles. This formed the basis for the CSI which describes the following eight types of shoppers:

- perfectionist/high quality-conscious shoppers, who are primarily concerned with quality and will not compromise with products classified as "good enough";

- brand-conscious shoppers, who prefer to buy expensive, well-known brands and believe that the higher the price of a product, the better the quality;

- novelty/fashion-conscious shoppers, who tend to seek out new things and keep up to date with new styles and fashion trends;

- recreational/hedonistic shoppers, who take pleasure in shopping and enjoy the stimulation of looking for and choosing products;

- price-conscious/value-conscious shoppers, who are concerned with getting lower prices and the best value-for-money;

- impulsive/careless shoppers, who do not plan their shopping, appear unconcerned with how much they spend and often regret their decisions;

- confused by over-choice shoppers, who demonstrate a lack of confidence and an inability to manage the number of choices available, and typically experience an information overload; and

- habitual/brand-loyal shoppers, who prefer to shop at the same stores and tend to buy the same brands each time.

Using a sample of students, each of these characteristics was measured by six Likert-scaled items scored from one to five, with ratings of "strongly agree" and "strongly disagree" as end points. It was found that the eight factors confirmed the characteristics proposed.

Hafstrom et al (1992) examined the cross-cultural applicability of the instrument developed by Sproles and Kendall (1986) using a sample of Korean students. All the factors, except novelty/fashion-consciousness, could be confirmed. However, an additional factor of time/energy conserving was suggested.

TABLE 3:

RESULTS FROM GOODNESS-OF-FIT TESTS

\begin{tabular}{|l|c|c|c|}
\hline & Chinese & Motswana & Caucasian \\
\hline Joreskog GFI & 0,490 & 0,499 & 0,447 \\
\hline Joreskog AGFI & 0,434 & 0,445 & 0,386 \\
\hline Bentler- Bonett Normed Fit Index & 0,219 & 0,178 & 0,208 \\
\hline Bentler-Bonett Non-Normed Fit Index & 0,253 & 0,184 & 0,203 \\
\hline Bentler Comparative Fit Index & 0,294 & 0,228 & 0,245 \\
\hline James-Mulaik-Brett Parsimonious Fit Index & 0,208 & 0,169 & 0,197 \\
\hline Bollen's Rho & 0,176 & 0,133 & 0,164 \\
\hline Bollen's Delta & 0,308 & 0,242 & 0,254 \\
\hline
\end{tabular}


Lyonski et al (1996) then tested the CSI with a sample of students in New Zealand, Greece, India and the USA and found that the CSI was more applicable to the developed countries (New Zealand and the USA) than to the developing countries (India and Greece). The authors speculated that the differences in the retail environment in India and Greece could explain why the inventory could not be applied to the two countries without modification of the instrument. Fan and Xiao (1998) tested the CSI with students in China and proposed the following dimensions: brand-consciousness; fashion-consciousness; quality-consciousness; price-consciousness; time-consciousness; impulsiveness; and information utilisation.

From the previous studies it seems as if the CSI in its original form cannot be generalised to different countries without some modification. However, Rosenthal and Rosnow (quoted in Walsh et al, 2001) suggest that a study needs to be replicated at least fifteen times before results can be generalised, indicating that additional work on the CSI is necessary. Furthermore, since database searches did not show previous research focused on a multi-cultural sample consisting of local and foreign cultures within South Africa, it is expected that the current study would make a contribution in this regard.

\section{METHODOLOGY}

\section{Focus and sample}

The study focused on decision-making styles associated with clothing purchases. Apparel is a highinvolvement shopping item that is often bought for its symbolic meaning, image reinforcement or psychological satisfaction, as it reflects the consumer's social life, aspirations, fantasies, affiliation and even the wearer's identity (Oh \& Fiorito, 2002). Furthermore, peers such as fellow students can exert an important influence on clothing purchases among young consumers (Skim et al in Beaudoin et al, 2003).

Students were selected as the sample as they represented a homogeneous group, allowing measurement equivalency across cultures and comparability of age and educational background. Since the students resided in the same city, they were exposed to the same marketing environment in terms of shopping malls, prices and promotional messages.

Data for this study came from a convenience sample of 100 students from China, having an Asian background; 100 students from Botswana, having an African background; and 100 South African students with a Caucasian background. Only Caucasian students were included so as to avoid the bias that could result from including various cultural orientations such as Xhosa, Sotho, Indian and local Chinese, among South Africans. While the size of the individual samples could be regarded as an important limitation of this study, the comparison of different cultural groups was expected to serve as an indication whether culture rather than retail environment deserves further investi- gation. Table 1 summarises the major demographic characteristics of the sample.

\section{The questionnaire}

The questionnaire comprised a few demographic questions and 40 Likert-scaled items scored from 1 (strongly disagree) to 5 (strongly agree) similar to that used by Sproles and Kendall (1986). To prevent order bias where prior questions might influence answers to subsequent questions (Aaker et al, 2004:327), individual items relating to specific factors as identified by Sproles and Kendall (1986), were not grouped together, but scrambled, using random digits from Saunders et al (2003:468).

A variety of mother tongues was represented within the three groups of respondents. Since all the respondents were taught in English, it was decided not to translate the questionnaire, as this would have resulted in numerous versions. A few of the 40 items of the original CSI (Sproles \& Kendall, 1986) were rephrased to more clearly reflect the focus on clothing and the sentence construction used in South Africa, but care was taken not to alter the basic meaning of the statements.

To verify and eliminate variation in respondents' understanding and interpretation of the questionnaire and any ambiguity in the wording, the questionnaire was pre-tested with ten respondents representative from each cultural group. Only a few minor changes had to be made.

\section{ANALYSIS OF THE DATA}

\section{Validation of the Sproles and Kendall CSI model}

To determine the commonality of the factors identified by Sproles and Kendall (1986) within the South African context, the 40 items were attributed to the respective factors according to the eight factors suggested by Sproles and Kendall and following the methods described by these authors. Table 2 shows the results of the original Sproles and Kendall model based on a USA sample compared with the results from applying this model to the three South African samples.

An analysis of Table 2 shows that in the case of the Chinese sample, the reliability coefficients of Factors 1, 5,6 and 8 were below 0,60, while only Factors 1 and 2 for the Motswana group had acceptable reliability coefficients. In the case of the Caucasian sample, six of the eight factors had acceptable reliability coefficients. Reliability coefficients lower than 0,60 are considered to be poor, but acceptable for exploratory research (Hair et al, 1998:118). Coefficients in the 0,70 range are deemed acceptable, and those over 0,80 , good (Sekaran, 2003:311). Only a few factors could therefore be confirmed for each of the three South African groups (six for the Caucasian sample, four for the Chinese sample, but only two for the Motswana sample). It is interesting that Factor 5 (price- 
TABLE 4: $\quad$ CHINESE DECISION-MAKING STYLES

\begin{tabular}{|c|c|c|c|}
\hline$\propto=0,74$ & $\begin{array}{l}\text { Factor 1: Perfectionist shopper } \\
\text { Factor mean score: } 3,48\end{array}$ & $\begin{array}{c}\text { Item } \\
\text { loading }\end{array}$ & $\begin{array}{l}\text { Mean } \\
\text { value }\end{array}$ \\
\hline 3 & The most expensive brands are usually my choice & $-0,365$ & 2,67 \\
\hline 10 & I take the time to shop carefully for best buys & 0,394 & 3,78 \\
\hline 11 & I have favourite brands that I buy over and over & 0,364 & 3,52 \\
\hline 27 & A product does not have to be perfect or the best to satisfy me & 0,554 & 3,55 \\
\hline 32 & I make special effort to choose the very best quality clothes & 0,402 & 3,59 \\
\hline 33 & In general, I usually try to buy the best overall quality & 0,392 & 3,53 \\
\hline 34 & To get variety, I shop at different shops & 0,375 & 3,68 \\
\hline 36 & I carefully watch how much I spend on clothing & 0,823 & 3,27 \\
\hline 38 & $\begin{array}{l}\text { When it comes to purchasing clothing, I try to get the very best or the per- } \\
\text { fect choice }\end{array}$ & 0,395 & 3,72 \\
\hline$\propto=0,84$ & $\begin{array}{l}\text { Factor 2: Hedonistic/recreational shopper } \\
\text { Factor mean score: } 3,33\end{array}$ & $\begin{array}{c}\text { Item } \\
\text { loading }\end{array}$ & $\begin{array}{l}\text { Mean } \\
\text { value }\end{array}$ \\
\hline 4 & It's fun to buy something new and exciting & 0,611 & 3,95 \\
\hline 9 & I enjoy shopping just for the fun of it & 0,553 & 3,48 \\
\hline 15 & Shopping at different stores wastes my time & $-0,689$ & 2,51 \\
\hline 17 & My shopping trips are fast & $-0,808$ & 2,85 \\
\hline 19 & I usually have one or more outfits of the very latest style & 0,419 & 3,76 \\
\hline 20 & Shopping is not a pleasant activity to me & $-0,661$ & 3,78 \\
\hline 22 & $\begin{array}{l}\text { I shop quickly, buying the first product or brand I find that seems good } \\
\text { enough }\end{array}$ & $-0,644$ & 2,69 \\
\hline 35 & Going shopping is one of the enjoyable activities of my life & 0,436 & 3,60 \\
\hline$\propto=0,70$ & $\begin{array}{l}\text { Factor 3: Impulsive/confused shopper } \\
\text { Factor mean score: } 3,03\end{array}$ & $\begin{array}{c}\text { Item } \\
\text { loading }\end{array}$ & $\begin{array}{l}\text { Mean } \\
\text { Value }\end{array}$ \\
\hline 16 & There are so many brands to choose from that I often feel confused & 0,453 & 2,84 \\
\hline 24 & All the information I get on different products confuses me & 0,754 & 3,06 \\
\hline 25 & I should plan my clothing shopping more carefully than I do & 0,424 & 3,01 \\
\hline 29 & I am impulsive when purchasing clothing & 0,549 & 3,04 \\
\hline 39 & I regularly change clothing brands & 0,534 & 3,21 \\
\hline$\propto=0,82$ & $\begin{array}{l}\text { Factor 4: Imagel/quality-conscious shopper } \\
\text { Factor mean score: } 3,09\end{array}$ & $\begin{array}{l}\text { Item } \\
\text { loading }\end{array}$ & $\begin{array}{l}\text { Mean } \\
\text { value }\end{array}$ \\
\hline 1 & I keep my wardrobe up-to date with changing fashions & 0,439 & 2,94 \\
\hline 2 & The higher the price of a product, the better its quality & 0,626 & 3,30 \\
\hline 3 & The most expensive brands are usually my choice & 0,682 & 2,67 \\
\hline 5 & Fashionable, attractive styling is very important to me & 0,624 & 3,57 \\
\hline 8 & Getting very good quality is very important to me & 0,467 & 3,62 \\
\hline 16 & There are so many brands to choose from that I often feel confused & 0,371 & 2,84 \\
\hline 21 & My standards and expectations for clothing I buy are high & 0,586 & 2,93 \\
\hline 26 & I prefer the best-selling brands & 0,562 & 2,85 \\
\hline$\propto=0,71$ & $\begin{array}{l}\text { Factor 5: Habitual shopper } \\
\text { Factor mean score: } 3,37\end{array}$ & $\begin{array}{l}\text { Item } \\
\text { loading }\end{array}$ & $\begin{array}{l}\text { Mean } \\
\text { value }\end{array}$ \\
\hline 11 & I have favourite brands that I buy over and over & 0,478 & 3,52 \\
\hline 13 & I go to the same stores each time I shop for clothing & 0,670 & 3,35 \\
\hline 14 & Once I find a brand I like, I stick with it & 0,557 & 3,25 \\
\hline
\end{tabular}

$\propto=$ Cronbach's coefficient alpha 
conscious/value-for-money), which had some of the lowest reliability coefficients in the Sproles and Kendall study, also had extremely low corresponding scores in the South African situation.

Further goodness-of-fit tests were performed. Table 3 shows that the results were unsatisfactory.

\section{Generation of a modified model applicable to the South African situation}

In an attempt to identify a more appropriate model for the South African situation, the data were factoranalysed using Principal Axis Factoring as method of extraction, followed by an oblique rotation (Direct Quartimin) (Gorsuch, 1997). Factor models consisting of five, six, seven, and eight factors each were scrutinized to find the optimum solution. Only items that contextually fitted the factor and which had a loading of 0,35 and higher were included in the subsequent analysis. Tables 4 to 6 show the optimum solution for each population group. Reported item numbers corresponded to those of the scrambled list.

\section{RESULTS}

Table 4 shows the results for the Chinese sample. Thirty-three items loaded onto five factors with Cronbach's coefficient alphas ranging from 0,70 to 0,84 . The inter-item correlations are shown in Table 5.

A five-factor model (shown in Table 6 ) best fitted the Motswana sample. Eighteen items loaded on these factors. Except for Factor 3, the reliability coefficients were all above 0,60 . Table 7 reflects the inter-item correlations.

Thirty-three items loaded on seven factors in the case of the Caucasian sample. The associated Cronbach coefficient alphas ranged from 0,66 to 0,84 . Table 8 shows the results of the factor grouping and Table 9 that of the inter-item correlations.

\section{DISCUSSION}

\section{Modified model of decision-making styles}

Subjecting the South African data set to exploratory factor analysis as described earlier, resulted in different factors with differing reliability coefficients and differing item loadings for the three samples. Five useful factors resulted for the Chinese and Motswana groups and seven for the Caucasian group. Three common shopping styles (perfectionist, hedonistic and habitual) were confirmed across all three groups, albeit with different item loadings (reported in Tables 4, 6 and 8 ). It was significant that for perfectionist, habitual and hedonistic shopping styles, the modified models had higher construct reliability for all cultural groups than when the data was subjected to the Sproles and Kendall factor and item groupings (Table 2).

It can also be noted from Tables 4, 6 and 8, that some items loaded on different factors for the different population groups. For example, item 34 (To get variety, I shop at different shops), loaded on the factor denoting a perfectionist shopping style for the Chinese data, but described a recreational/hedonistic shopping style in the case of the Motswana data. Whereas the Chinese student might see shopping for variety at different stores as being part of the perfect clothing selection, Motswana students might shop for variety at different stores because they generally enjoy shopping. The same item thus reflected different consumer decisionmaking styles within the different cultures.

Some items also loaded on two factors within the same population group. Examples are items 3 and 11 in the case of the Chinese sample. Although it can be argued that items could fit with both the factors, it was interesting that the comparatively higher scores occurred where the particular item made more theoretical sense.

Using the items from the various factors to describe the typical decision-making styles of the three cultural groups resulted in some interesting observations. For example, Chinese students scoring high on the perfectionist dimension, would typically take time to shop for the best buys and quality and buy their favourite brands over and over presumably since these represent the perceived best quality and hence the perceived best buy. Perfectionism would also mean carefully watching how much they spend and looking for the very best choice. Motswana students scoring high on the perfectionist dimension are also likely to make a special effort to get the very best quality and choice. Shopping at different stores is, however, an indication of their enjoyment of this activity rather than of their trying to find the best product. Caucasian students scoring high on the perfectionist dimension are expected to be quality-conscious and make a special effort to find the best value-for-money and in this respect more closely resemble the decision-making style of Chinese students than that of Motswanas.

Chinese and Motswana students with high scores on the hedonistic/recreational dimension would probably view shopping as a fun-activity and would not mind spending time shopping at different stores. Having outfits in the latest styles would be indicative of Chinese students' enjoyment of shopping rather than of their being image- conscious. Caucasian students scoring high on the hedonistic/recreational dimension would tend to spend much time on this joyous activity. They would therefore not choose the first product that seems good enough, but be prepared to spend time looking for the perfect buy.

Chinese students with high scores on the impulsive/ confused dimension are likely to be bewildered by all the information and brands available in South Africa. They would tend to be impulsive, but realise that they should plan their shopping more carefully. Caucasian students who scored high on the information overload and confused dimensions, would show a decisionmaking style similar to that of the Chinese students. No factor describing confusion or information overload 
TABLE 5: $\quad$ CHINESE FACTOR CORRELATION MATRIX

\begin{tabular}{|c|c|c|c|c|c|}
\hline FACTOR & $\mathbf{1}$ & $\mathbf{2}$ & $\mathbf{3}$ & $\mathbf{4}$ & $\mathbf{5}$ \\
\hline $\mathbf{1}$ & 1,00 & & & & \\
\hline $\mathbf{2}$ & $-0,33$ & 1,00 & & & \\
\hline $\mathbf{3}$ & $-0,08$ & 0,13 & 1,00 & & \\
\hline $\mathbf{4}$ & $-0,24$ & 0,06 & 0,26 & 1,00 & \\
\hline $\mathbf{5}$ & 0,11 & $-0,15$ & $-0,20$ & $-0,27$ & 1,00 \\
\hline
\end{tabular}

TABLE 6: MOTSWANA DECISION-MAKING STYLES

\begin{tabular}{|c|c|c|c|}
\hline$\propto=0,87$ & $\begin{array}{l}\text { Factor 1: Perfectionist shopper } \\
\text { Factor mean score: } 3,86\end{array}$ & $\begin{array}{l}\text { Item } \\
\text { loading }\end{array}$ & $\begin{array}{l}\text { Mean } \\
\text { Value }\end{array}$ \\
\hline 32 & I make special effort to choose the very best quality clothes & 0,902 & 3,68 \\
\hline 33 & In general, I usually try to buy the best overall quality & 0,675 & 3,92 \\
\hline 38 & $\begin{array}{l}\text { When it comes to purchasing clothing, I try to get the very best or the per- } \\
\text { fect choice }\end{array}$ & 0,677 & 3,98 \\
\hline$\propto=0,70$ & $\begin{array}{l}\text { Factor 2: Image/quality-conscious shopper } \\
\text { Factor mean score: } 3,23\end{array}$ & $\begin{array}{c}\text { Item } \\
\text { loading }\end{array}$ & $\begin{array}{l}\text { Mean } \\
\text { value }\end{array}$ \\
\hline 1 & I keep my wardrobe up-to date with changing fashions & 0,438 & 2,82 \\
\hline 2 & The higher the price of a product, the better its quality & 0,583 & 3,70 \\
\hline 3 & The most expensive brands are usually my choice & 0,729 & 3,04 \\
\hline 6 & I prefer buying well-known national brands & 0,352 & 3,14 \\
\hline 11 & I have favourite brands that I buy over and over & 0,548 & 3,55 \\
\hline 21 & My standards and expectations for clothing I buy are high & 0,480 & 3,15 \\
\hline$\propto=0,58$ & $\begin{array}{l}\text { Factor 3: Habitual shopper } \\
\text { Factor mean score: } 2,91\end{array}$ & $\begin{array}{c}\text { Item } \\
\text { loading }\end{array}$ & $\begin{array}{l}\text { Mean } \\
\text { value }\end{array}$ \\
\hline 13 & I go to the same stores each time I shop for clothing & 0,388 & 3,03 \\
\hline 14 & Once I find a brand I like, I stick with it & 0,966 & 2,78 \\
\hline$\propto=0,66$ & $\begin{array}{l}\text { Factor 4: Careless shopper } \\
\text { Factor mean score: } 2,57\end{array}$ & $\begin{array}{c}\text { Item } \\
\text { loading }\end{array}$ & $\begin{array}{l}\text { Mean } \\
\text { value }\end{array}$ \\
\hline 20 & Shopping is not a pleasant activity to me & 0,378 & 2,42 \\
\hline 22 & $\begin{array}{l}\text { I shop quickly, buying the first product or brand I find that seems good } \\
\text { enough }\end{array}$ & 0,829 & 2,64 \\
\hline 31 & I really do not give my clothing purchases much thought or care & 0,450 & 2,64 \\
\hline$\propto=0,67$ & $\begin{array}{l}\text { Factor 5: Hedonistic/recreational shopper } \\
\text { Factor mean score: } 3,05\end{array}$ & $\begin{array}{c}\text { Item } \\
\text { loading }\end{array}$ & $\begin{array}{l}\text { Mean } \\
\text { value }\end{array}$ \\
\hline 15 & Shopping at different stores wastes my time & $-0,540$ & 2,17 \\
\hline 20 & Shopping is not a pleasant activity to me & $-0,479$ & 2,42 \\
\hline 34 & To get variety, I shop at different shops & 0,643 & 4,18 \\
\hline 35 & Going shopping is one of the enjoyable activities of my life & 0,653 & 3,44 \\
\hline
\end{tabular}

$\propto=$ Cronbach's coefficient alpha 
TABLE 7: $\quad$ MOTSWANA FACTOR CORRELATION MATRIX

\begin{tabular}{|c|c|c|c|c|c|}
\hline FACTOR & $\mathbf{1}$ & $\mathbf{2}$ & $\mathbf{3}$ & $\mathbf{4}$ & $\mathbf{5}$ \\
\hline $\mathbf{1}$ & 1,00 & & & & \\
\hline $\mathbf{2}$ & 0,09 & 1,00 & & & \\
\hline $\mathbf{3}$ & 0,17 & 0,18 & 1,00 & & \\
\hline $\mathbf{4}$ & $-0,12$ & $-0,11$ & $-0,09$ & 1,00 & $-0,21$ \\
\hline $\mathbf{5}$ & 0,21 & 0,16 & 0,02 & 1,00 \\
\hline
\end{tabular}

TABLE 8: $\quad$ CAUCASIAN DECISION-MAKING STYLES

\begin{tabular}{|c|c|c|c|}
\hline$\propto=0,77$ & $\begin{array}{l}\text { Factor 1: Information overload shopper } \\
\text { Factor mean score: } 2,52\end{array}$ & $\begin{array}{l}\text { Item } \\
\text { loading }\end{array}$ & $\begin{array}{l}\text { Mean } \\
\text { Value }\end{array}$ \\
\hline 16 & There are so many brands to choose from that I often feel confused & 0,504 & 2,47 \\
\hline 23 & $\begin{array}{l}\text { The more I learn about clothing products, the harder it seems to choose } \\
\text { the best }\end{array}$ & 0,591 & 2,42 \\
\hline 24 & All the information I get on different products confuses me & 0,718 & 2,19 \\
\hline 37 & Sometimes it is hard to decide at which stores to shop & 0,580 & 3,01 \\
\hline$\propto=0,80$ & $\begin{array}{l}\text { Factor 2: Hedonistic/time-conscious shopper } \\
\text { Factor mean score: } 2,97\end{array}$ & $\begin{array}{l}\text { Item } \\
\text { loading }\end{array}$ & $\begin{array}{l}\text { Mean } \\
\text { value }\end{array}$ \\
\hline 9 & I enjoy shopping just for the fun of it & $-0,736$ & 3,00 \\
\hline 17 & My shopping trips are fast & 0,814 & 3,07 \\
\hline 20 & Shopping is not a pleasant activity to me & 0,758 & 2,54 \\
\hline 22 & $\begin{array}{l}\text { I shop quickly, buying the first product or brand I find that seems good } \\
\text { enough }\end{array}$ & 0,541 & 2,37 \\
\hline 27 & A product does not have to be perfect, or the best, to satisfy me & 0,508 & 3,24 \\
\hline 34 & To get variety, I shop at different shops & $-0,393$ & 3,61 \\
\hline$\propto=0,84$ & $\begin{array}{l}\text { Factor 3: Brand-conscious shopper } \\
\text { Factor mean score: } 2,66\end{array}$ & $\begin{array}{l}\text { Item } \\
\text { loading }\end{array}$ & $\begin{array}{l}\text { Mean } \\
\text { value }\end{array}$ \\
\hline 3 & The most expensive brands are usually my choice & 0,713 & 2,45 \\
\hline 6 & I prefer buying well-known national brands & 0,740 & 2,88 \\
\hline 26 & I prefer the best-selling brands & 0,771 & 2,59 \\
\hline 30 & The most advertised brands are usually good choices & 0,755 & 2,70 \\
\hline$\propto=0,66$ & $\begin{array}{l}\text { Factor 4: Habitual shopper } \\
\text { Factor mean score: } 3,20\end{array}$ & $\begin{array}{l}\text { Item } \\
\text { loading }\end{array}$ & $\begin{array}{l}\text { Mean } \\
\text { value }\end{array}$ \\
\hline 14 & Once I find a brand I like, I stick with it & 0,633 & 3,08 \\
\hline 29 & I am impulsive when purchasing & $-0,533$ & 2,72 \\
\hline 34 & To get variety, I shop at different shops & $-0,447$ & 3,61 \\
\hline 39 & I regularly change clothing brands & $-0,823$ & 3,38 \\
\hline$\propto=0,72$ & $\begin{array}{l}\text { Factor 5: Price-conscious shopper } \\
\text { Factor mean score: } 3,54\end{array}$ & $\begin{array}{l}\text { Item } \\
\text { loading }\end{array}$ & $\begin{array}{l}\text { Mean } \\
\text { value }\end{array}$ \\
\hline 2 & The higher the price of a product, the better its quality & 0,518 & 3,24 \\
\hline 12 & I buy as much of my clothing as possible at sale prices & 0,354 & 3,25 \\
\hline 18 & I look carefully to find the best value-for-money & 0,419 & 4,10 \\
\hline 36 & I carefully watch how much I spend on clothing & 0,858 & 3,55 \\
\hline$\propto=0,70$ & $\begin{array}{l}\text { Factor 6: Confused shopper } \\
\text { Factor mean score: } 2,63\end{array}$ & $\begin{array}{l}\text { Item } \\
\text { loading }\end{array}$ & $\begin{array}{l}\text { Mean } \\
\text { value }\end{array}$ \\
\hline 13 & I go to the same stores each time I shop for clothing & 0,404 & 3,24 \\
\hline 15 & Shopping at different stores wastes my time & 0,828 & 2,22 \\
\hline 25 & I should plan my clothing shopping more carefully than I do & 0,674 & 2,47 \\
\hline 40 & I often make careless purchases I later wish I had not made & 0,525 & 2,57 \\
\hline
\end{tabular}


TABLE 8: CAUCASIAN DECISION-MAKING STYLES (continued ....)

\begin{tabular}{|l|l|l|l|}
\hline$\propto=\mathbf{0 , 8 1}$ & $\begin{array}{l}\text { Factor 7: Perfectionist shopper } \\
\text { Factor mean score: } \mathbf{3 , 6 7}\end{array}$ & $\begin{array}{l}\text { Item } \\
\text { loading }\end{array}$ & $\begin{array}{l}\text { Mean } \\
\text { Value }\end{array}$ \\
\hline 8 & Getting very good quality is very important to me & 0,754 & 3,91 \\
\hline 11 & I have favourite brands that I buy over and over & 0,587 & 3,38 \\
\hline 18 & I look carefully to find the best value-for-money & 0,541 & 4,10 \\
\hline 21 & My standards and expectations for clothing I buy are high & 0,455 & 3,50 \\
\hline 32 & I make special effort to choose the very best quality clothes & 0,678 & 3,51 \\
\hline 33 & In general, I usually try to buy the best overall quality & 0,720 & 3,82 \\
\hline 38 & $\begin{array}{l}\text { When it comes to purchasing clothing, I try to get the very best or the } \\
\text { perfect choice, }\end{array}$ & 0,524 & 3,46 \\
\hline
\end{tabular}

$\propto=$ Cronbach's coefficient alpha

TABLE 9: CAUCASIAN FACTOR CORRELATION MATRIX

\begin{tabular}{|c|c|c|c|c|c|c|c|}
\hline FACTOR & $\mathbf{1}$ & $\mathbf{2}$ & $\mathbf{3}$ & $\mathbf{4}$ & $\mathbf{5}$ & $\mathbf{6}$ & $\mathbf{7}$ \\
\hline $\mathbf{1}$ & 1,00 & & & & & & \\
\hline $\mathbf{2}$ & $-0,23$ & 1,00 & & & & & \\
\hline $\mathbf{3}$ & 0,17 & 0,06 & 1,00 & & & & \\
\hline $\mathbf{4}$ & 0,03 & 0,11 & $-0,08$ & 1,00 & & & \\
\hline $\mathbf{5}$ & 0,04 & 0,02 & $-0,01$ & 0,05 & 1,00 & & \\
\hline $\mathbf{6}$ & 0,15 & $-0,06$ & 0,34 & $-0,12$ & $-0,09$ & 1,00 & \\
\hline $\mathbf{7}$ & 0,11 & 0,08 & 0,11 & $-0,12$ & 0,23 & 0,18 & 1,00 \\
\hline
\end{tabular}

resulted from the analysis of the Motswana data.

Chinese students scoring high on the image/quality dimension would typically keep their wardrobe up-todate with the latest fashion, equate high quality with high price and buy the most expensive, best-selling brands. Motswana students with high scores are likely to show a very similar decision-making style. Image/ quality-consciousness did not result as a dimension from the analysis of the Caucasian data. Rather, this group seem to be more brand and price conscious. Students scoring high on the brand-conscious dimension would seek out expensive, well-known national and best-selling, well-advertised brands. The priceconscious Caucasian student would typically carefully consider value-for-money, control spending on clothing and often buy at sale prices. Watching spending on clothing would be typical of the perfectionist shopping style of the Chinese student. Price-consciousness did not seem to feature dominantly among Motswana students.

Chinese and Motswana students with high scores on the habitual dimension would tend to have favourite brands that they buy over and over, patronising the same clothing shops. Caucasian students scoring high on the habitual dimension would most likely be loyal to the brands and stores of their choice.

\section{Consumer decision-making characteristics of Chi- nese, Motswana and Caucasian students}

Tables 4, 6 and 8 also show the mean values resulting from the data analysis. Negatively worded statements were reversed. The findings revealed some interesting patterns in the shopping characteristics of Chinese, Motswana and Caucasian students.

A comparison of the factor mean scores shows that while shopping for clothing in South Africa, Chinese students most strongly exhibit a decision-making style typical of the perfectionist shopper $(3,48)$, followed by that of the habitual shopper $(3,37)$ and the hedonisticl recreational shopper $(3,33)$. Typical individual characteristics include enjoying buying something new $(3,95)$ and taking time to find the best buys $(3,78)$. Motswana students exhibited a typical perfectionist shopping style $(3,86)$, but were also image and quality conscious $(3,23)$. They particularly shop for variety $(4,14)$ and try to find the perfect choice $(3,98)$. While also being perfectionist shoppers $(3,67)$, Caucasian students exhibited characteristics typical of the priceconscious shopper $(3,54)$. They carefully look for the best value-for-money $(4,10)$ and try to get good quality $(3,91)$.

\section{CONCLUSIONS}

This research was a first attempt at verifying the applicability of the Sproles and Kendall (1986) model within 
a South African retail environment. It also contributed to the profiling of consumer decision-making styles of Caucasian students compared with their foreign counterparts from China and Botswana when doing their clothing shopping in South Africa. It was interesting to find that although students from all three cultural groups seemed to be perfectionist shoppers, Chinese students are typically habitual shoppers, while Motswana students are image and quality-conscious and Caucasians are price-conscious. This could also explain why Caucasian students had the lowest expenditure on clothing of all three groups.

The current research confirmed the view of Lyonski et al (1996) that the original CSI index developed by Sproles and Kendall (1986) is more applicable to Western, developed cultures. Despite rather poor general applicability of the original Sproles and Kendall (1986) CSI in the South Africa situation, the best results were still obtained for the Caucasian group, with fairly good results for the Chinese group. However, the index did not seem to be applicable to the Motswana data set.

Since a number of the original 40 items did not have acceptable scores in the 'fit' of both the original and modified decision-making models, and furthermore loaded on different factors in the case of the different cultural groups, it is clear that additional culturespecific dimensions should be investigated. Particular attention will have to be focused on consumers from an African culture.

Significant differences were found in the applicability of the instrument and in the decision-making styles of the three cultural groups, despite their exposure to the same marketing environment in Port Elizabeth. This seems to point to culture and not retail environment (as argued by Lyonski et al, 1996) as the possible reason for the non-applicability of the original index to consumers from different cultures. Since the relative small size of the respective samples of the current study could be regarded as a limiting factor, further research employing larger samples should be undertaken. A verification of decision-making styles with respect to speciality products such as vehicles compared with shopping goods and convenience goods, would further confirm the general applicability of the consumer decision-making styles index.

\section{REFERENCES}

AAKER, DA, KUMAR, V \& DAY, GS. 2004. Marketing research. Hoboken, New Jersey. John Wiley.

BEAUDOIN, P, LACHANCE, MJ \& ROBITAILLE, J. 2003. Fashion innovativeness, fashion diffusion and brand sensitivity among adolescents. Journal of Fashion Marketing and Management 7(1):23-30.

FAN, JX \& XIAO, J. 1998. Consumer decisionmaking styles of young-adult Chinese. The Journal of Consumer Affairs 32(2):275-294.

GORSUCH, RL. 1997. Exploratory factor analysis: its role in item analysis. Journal of Personality Assessment 68(3):532-560.

HAFSTROM, JL, CHAE, JS \& CHUNG, Y. 1992. Consumer decision-making styles: comparison between the United States and Korean young consumers. The Journal of Consumer Affairs 26:146-158.

HAIR, JF, ANDERSON, RE, TATHAM, RL \& BLACK, WC. 1998. Multivariate data analysis. 5th ed. Upper Saddle River, New Jersey. Prentice-Hall.

LYONSKI, S, DURVASULA, S \& ZOTOS, Y. 1996. Consumer-decision-making styles: a multi-country investigation. European Journal of Marketing 30 (12):10-21.

NELSON MANDELA METROPOLITAN UNIVERSITY. 2006. Student diary. Port Elizabeth.

$\mathrm{OH}, \mathrm{J} \& \mathrm{FIORITO}, \mathrm{SS} .2002$. Korean women's clothing brand loyalty. Journal of Fashion Marketing and Management 6(3):206-222.

SAUNDERS, M, LEWIS, P \& THORNHILL, A. 2003. Research methods for business students. 3rd ed. London. Prentice-Hall.

SCHIFFMAN, LG \& KANUK, LL. 2004. Consumer behavior. 8th ed. Upper Saddle River, New Jersey. Prentice-Hall.

SEKARAN, U. 2003. Research methods for business. 4th ed. New York. Wiley.

SPROLES, GB \& KENDALL, E. 1986. A methodology for profiling consumers' decision-making styles. The Journal of Consumer Affairs 20(2):267-279.

WALSH, G, MITCHELL, $V$ \& HENNIG-THURAU, T. 2001. German consumer decision-making styles. The Journal of Consumer Affairs 35(1):73-95. 